\title{
Review
}

\section{A review of research on the negative accounting relationship between risk and return: Bowman's paradox}

\author{
Manuel Núñez Nickel ${ }^{\mathrm{a}, *}$, Manuel Cano Rodriguez ${ }^{\mathrm{b}}$ \\ ${ }^{a}$ Department of Business Economics, Carlos III University, C Madrid, 126; 28903 Getafe-Madrid, Spain \\ ${ }^{\mathrm{b}}$ Department of Business Administration, Accounting and Sociology, University of Jaén, Paraje las Lagunillas s/n; 23071 - Jaén, Spain
}

Received 15 March 2000; accepted 21 September 2001

\begin{abstract}
A cornerstone in finance theory continues to be the positive relationship between risk and return in spite of Fama and French (The Journal of Finance 47(2) (1992) 427-65) and several later papers finding no relationship between the two variables. Twelve years earlier, Bowman (Sloan Management Review 1980, pp. 17-31) studied the same relationship from organization theory, achieving similar results with accounting data, and developing a whole research stream known as "Bowman's paradox". This stream has contributed to some curious and interesting ideas that could also be applied to other different streams: new risk measures, managerial goal selection, response to the decline in the organization, diversification strategy on risk and return, among others. Similar to the financial stream, a number of researchers have tried to study this issue from the strategic management perspective. Their inconclusive results have generated a considerable controversy, keeping this research stream alive. In this work, we describe and explore this phenomenon from "Bowman's paradox", theoretical explanations, criticisms and future orientations.
\end{abstract}

Keywords: Risk-return relationship; Bowman's paradox; Accounting risk

\section{Contents}

1 Introduction

2 General focus on accounting relationship: organization theory

3 Theoretical explanations in organization theory 3

3.1 Management behavior towards risk 3

3.1.1 Prospect theory

3.1.2 Behavioral theory

3.2 Strategic position and competitive advantage

3.2.1 Diversification strategy

3.2.2 Market power

3.2.3 The impact of previous risk on return

4 Criticisms of the methodology in organization theory

4.1 Statistical measures

4.2 Sample criticisms

5 Conclusions and future research

Appendix A

References

\footnotetext{
This research was funded by FEGA-FEOGA $(305 / 166)$ and DGES (PB 97-13.58) August, 2001.

* Corresponding author. Tel.: +34-91-624-58-46; fax: +34-91-624-96-07.

E-mail addresses: mnunez@emp.uc3m.es (M.N. Nickel), mcano@ujaen.es (M.C. Rodriguez).
}

\section{Introduction}

A cornerstone in finance theory is the positive relationship between risk and return [3, p. 244]. This relationship arises mainly from a risk-averse reasoning: people will not support higher risk for the same level of return; they will only accept higher risk if they get a higher return. This relationship has been widely tested with financial data from the stock market, using the beta of capital assets pricing model (CAPM) as the risk measure, and the results achieved are contradictory. Until the work by Fama and French [1], most research had obtained a significant positive relationship, as the CAPM theory postulates. From Fama and French [1] onwards, a new research stream in financial economics, known as "the death of beta" has arisen [4,5], which includes tests that have reported positive, negative or no correlation at all between return and beta (e.g., [3,6,7]). This new research stream is therefore challenging some of the more established assumptions in financial economics.

Twelve years before Fama and French's paper [1], Bowman [2] studied the same relationship from organization theory, achieving similar results with accounting data; that is to say, a negative slope between risk and return. From this work, another totally independent research stream, known 


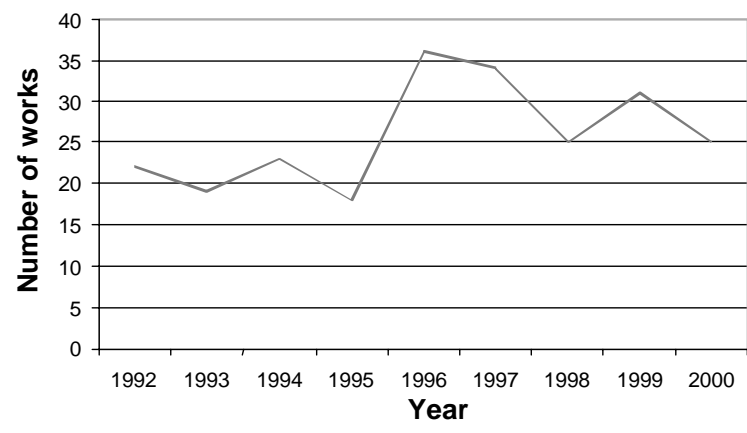

Fig. 1. Works that cited Bowman's paradox articles, from 1992 to 2000 .

as Bowman's paradox has arisen because, at that time, it went against the established financial economics tenet. This paradox implies that managers accept higher risk at the same time that they expect lower returns. To date, similar to the financial stream, a number of researchers have tried to study this issue from the strategic management focus. They obtained inconclusive results that have generated a considerable controversy that continues with no consensus emerging [8, p. 330].

The importance of this research stream is demonstrated by the key issues that management scholars are currently studying. These originate in the works that described this paradoxical relationship, and whose ideas can also be applied to different streams. For instance, since the traditional risk measures (e.g. beta) present problems, it is possible to use measures of strategic risk specifically developed by this stream [9]. The research on other interesting topics, such as managerial goal selection, the response to the decline in the organizations, the influence of the diversification strategy on risk and return, or the relationship between accounting and market variables, has also been enhanced by these works.

An intuitive idea of the depth of Bowman's paradox can be obtained through Fig. 1, which shows the number of works that cite all the articles reviewed in this survey between 1992 and 2000. Among these papers we find both works about Bowman's paradox and papers that, from outside this line of thought, rest on it to develop some feature of their own theories. In Fig. 1 we can see that, although the maximum interest in this topic was reached in 1996 and 1997 , there is a clearly global positive trend, and the number of works continue to increase. (See Appendix A for specific analysis by paper.)

We think that it is important to review this literature for several reasons: (1) There is at present considerable controversy because of the contradictions, gaps, and inconsistencies in this literature. Thus, as there is no agreement between researchers of this topic, it is interesting to study in depth the problems that prevent this consensus. (2) Although there are significant differences between Beta's death and Bowman's paradox streams, both pursue the same goal: the relation be- tween risk and return. Nevertheless, in the whole literature of Beta's death there is no citation of Bowman's paradox. If we assume that the financial stream is successful at this time [10], that is, that the beta as measure of market risk has failed [11], we can see why financial scholars are looking for new risk measures, mainly from accounting [12,33]. In this sense, we think that it is possible that in the very near future both streams will achieve their results together. ${ }^{1}$ (3) Although we are discussing accounting measures, there are only citations from financial and organization theories. Accounting research could add a valuable new focus, and contribute with its own tenet about more sophisticated risk measures, as in the case of Kim and Ismail [12].

For these reasons, we agree with Ruefli [9] that: "an important step would be to examine and reexamine the nature of the risk-return relationships for the various samples examined."

In this paper, the literature about the relationship between risk and return is reviewed. The targets are to define and clarify the relationship through this literature, summarize previous investigations in order to inform the reader of the state of current research, identify relations and inconsistencies between (and inside) different theories, and suggest new openings for future research.

The rest of the paper is organized as follows. First, the survey structure is explained, distinguishing between the two main groups of studies: theoretical explanations and empirical criticisms. Second, the works included in the first group are surveyed according to their theoretical backgrounds. Third, the main criticisms made about the empirical research of the paradox are reviewed. Finally, we extract some conclusions from the literature examined, with special mention of those research foci that are still to be addressed in depth.

\section{General focus on accounting relationship: organization theory}

Some works before Bowman [2] tested the relationship between return and risk with accounting measures, finding a theoretical positive relationship or no significant relationship. These works are presented in Table 1. It was Bowman [2] who first pointed out the paradoxical negative relationship. From this initial work, a new research stream grew, centered on the risk-return relationship using accounting variables. The objective of this work is a review of the literature from the discovery of the paradox, and, therefore, it will be centered on those articles that have tested this relationship from Bowman's pioneer work.

\footnotetext{
${ }^{1}$ To date, only four papers simultaneously investigate the riskreturn relationship in financial and organizational terms, always from management literature [13-15,9].
} 
Table 1

Empirical risk-return papers before Bowman [2]

\begin{tabular}{|c|c|c|c|c|c|c|c|}
\hline \multirow[t]{2}{*}{ Researchers } & \multicolumn{2}{|l|}{ Measures } & \multicolumn{4}{|l|}{ Sample } & \multirow{2}{*}{$\frac{\text { Results }}{\text { Relationship }}$} \\
\hline & Return & Risk & Firms & Industries & Source & Period & \\
\hline $\begin{array}{l}\text { Conrad and } \\
\text { Plotkin [16] }\end{array}$ & ROA & $\begin{array}{l}\text { ROA } \\
\text { dispersion }\end{array}$ & 763 & 59 & Compustat & $1950-1965$ & Positive \\
\hline $\begin{array}{l}\text { Fisher and } \\
\text { Hall [17] }\end{array}$ & ROA & $\begin{array}{l}\text { ROA variance } \\
\text { and skewness }\end{array}$ & $\begin{array}{l}\text { Not } \\
\text { mentioned }\end{array}$ & 11 & $\begin{array}{l}\text { Not } \\
\text { mentioned }\end{array}$ & $1950-1964$ & $\begin{array}{l}\text { Significant positive at } \\
\text { firm and industry level }\end{array}$ \\
\hline Hurdle [18] & $\begin{array}{l}\text { Stockholder } \\
\text { profitability }\end{array}$ & $\begin{array}{l}\text { Absolute devi- } \\
\text { ation of return } \\
\text { measure }\end{array}$ & 231 & 85 & Sheperd & $1960-1969$ & Significant positive \\
\hline $\begin{array}{l}\text { Armour and } \\
\text { Teece [19] }\end{array}$ & ROE & ROE variance & 28 & 1 & Fortune 500 & $1955-1973$ & Not significant negative \\
\hline Bowman [2] & ROE & ROE variance & $\begin{array}{r}387 \\
1572\end{array}$ & $\begin{array}{l}11 \\
85\end{array}$ & Value Line & $\begin{array}{l}1955-1973 \\
1968-1976\end{array}$ & $\begin{array}{l}\text { Negative at firm level, } \\
\text { no significant at industry level }\end{array}$ \\
\hline
\end{tabular}

Two main research themes can be addressed as they apply to the study of "Bowman's paradox". The first is composed of those works that assume the possibility of a negative riskreturn relationship, hypothesizing this relationship from their theoretical backgrounds. In other words, they are works that justify the paradox theoretically. The second is composed of works that address the methodological mistakes present in the previous studies. For these studies, these methodological problems condition the acceptance of the negative riskreturn relationship. Within the studies that follow the first guideline, there are two main points of view from which the paradox is explained [20, p. 271]: (1) the decision-maker behavior toward risk, which is studied mainly from prospect theory [21] and behavioral theory [22]; (2) the privileges of the strategic position of the firm. In this group of studies, issues such as the diversification strategy [23,24], the market power [25] or the negative effects of the historic risk on the return $[26,14,27]$ are related to the risk-return association.

For the studies that follow the second theme, we address the criticisms that several researchers have stated about the sample, measures, and statistical methodology followed in the first group of studies.

An overview of the theories that attempt to explain the negative relationship and the main criticisms about the empirical research will be presented to facilitate future research about the paradox. Following the example of Bruno Latour's diagrams [28], Fig. 2 shows the structure of these groups of studies.

The arrows have the following explanations: (a) arrows pointing to the circle represent agreement with Bowman's paradox; (b) arrows pointing away from the circle indicate that the researcher(s) dissents from Bowman's conclusions; and (c) arrows pointing in both directions, joining the circle with some researcher(s) indicate that this study has been undertaken by some component of Bowman's investigation team.

\section{Theoretical explanations in organization theory}

Those researchers who assume the existence of a negative relationship between return and risk with accounting measures have sought to explain such a relationship through certain theories. These works can be grouped into two types: the decision-maker behavior towards risk and the strategic position of the firm.

\subsection{Management behavior towards risk}

Decision theory accepts three attitudes towards risk [29, p. 72]: (1) risk averse: investments with less risk will be preferred at the same expected return level. (2) risk seeking: investments with higher risk will be preferred at the same expected return level. These decision makers will assume higher risk because they will get higher probability of reaching extraordinary returns because of the high variance values. (3) risk neutral: the higher expected return investment will be selected, independent of its risk level.

Although these three behaviors have been acknowledged, risk aversion has been a constant in the investment selection models [21, p. 264], [30, p. 5], [58, p. 11]. This risk aversion leads to a positive relationship between return and risk: risk-averse decision makers will choose high-risk alternatives only if they also offer high expected values [58, p. 11]. If the decision maker was risk seeking, the relationship between risk and return would be negative. Now, both high return and high risk will increase the utility of the subject. If two alternatives offer the same expected return, that which offers higher risk will be preferred, because it will allow higher probability of extraordinary returns. Hence, a lower profitability investment will not be selected unless it offers a high variance too; that is to say, if we decrease the expected return, it is because we are also increasing the risk. 


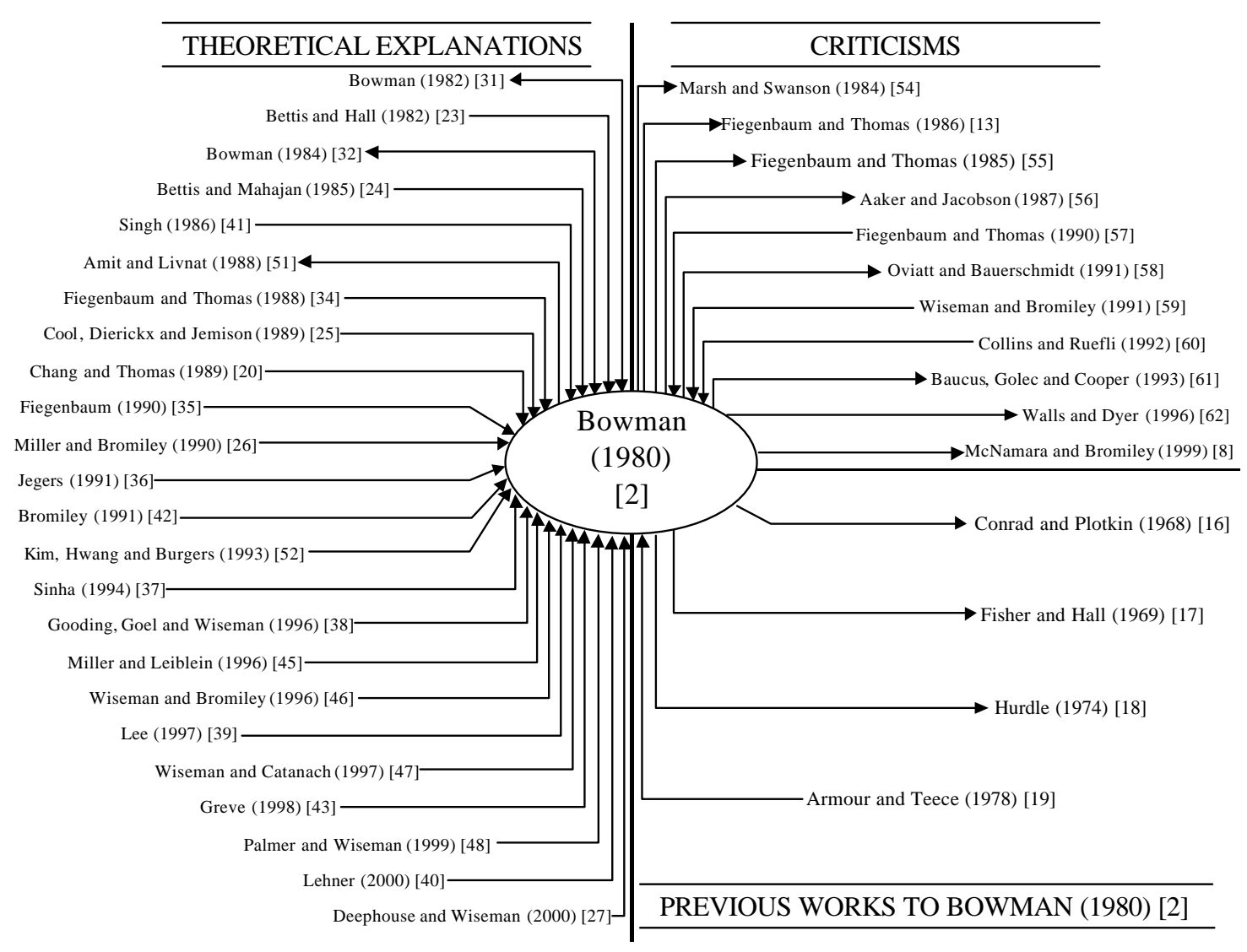

Fig. 2. Survey structure.

A risk-averse behavior leads to a positive relationship between risk and return, and a risk-seeking behavior leads to a negative relationship. As Bowman [2] found a negative relationship between accounting risk and accounting return, it makes the traditional assumption about risk-averse behavior questionable. However, as a constant risk-seeking behavior is "rather unlikely and contrary to most economic thought" [2, p. 25], the risk preference could change; that is to say, be dependent on the context of a choice [58, p. 5]. Thus, in some circumstances, individuals can be risk averse and, in other circumstances, can be risk seeking or risk neutral.

Two theories that assume this changeable behavior have been used to explain the "Bowman's paradox". These theories are "Prospect Theory" [21] from economic theory, and "Behavioral Theory" [22] from organizational theory.

\subsubsection{Prospect theory}

This theory was developed to explain some empirical results that contradict the traditional expected return theory. One of the main propositions of prospect theory points out the key role of the reference point or target for defining the decision maker's attitude towards risk. When the expected results of an alternative are "good" - that is to say, they are higher than the target level - the decision maker shows a risk-averse attitude. When the expected results are "bad" lower than the target level — the decision maker will be risk seeking. High expected results lead to a risk-averse attitude and, therefore, a positive risk-return relationship, while low expected results lead to a risk-seeking attitude and, hence, a negative relationship. Prospect theory also points out that this second relationship will be steeper than the first [21, p. 280].

Though prospect theory was developed to explain individual decision-making, some researchers $[31,32,34-36]$ consider that prospect theory postulates can also be applied to organizational decision-making. Such postulates are translated in a double relationship between risk and return: those firms that have reached their target levels (high return firms) will show risk-averse behavior; those firms that have not reached their target levels (low return firms) will be risk seeking. Then, the former firms will show a positive relationship between risk and return, and the latter, a negative relationship.

Fig. 3 shows the graphic relationship between risk and return [34, p. 98]. 


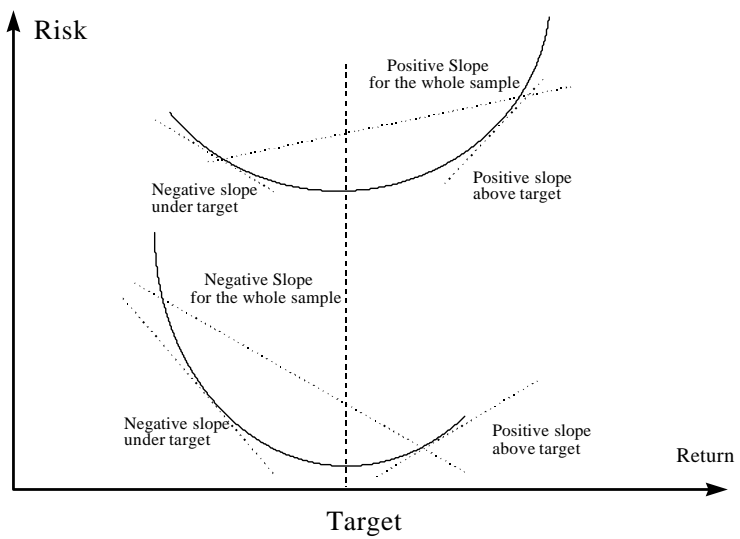

Fig. 3. Prospect theory's hypothesis and risk-return relationship.

The upper figure corresponds to a sample where most firms have reached the target level. Therefore, the relationship between risk and return for these firms is positive. Fewer firms have not reached the target level, presenting a negative slope relationship. However, for the whole sample, the obtained relationship is positive.

The lower figure presents the opposite: most firms have not reached the target level, so these firms present a negative risk-return relationship. Fewer firms present a positive relationship and their position is above the target. Overall, the stronger negative relationship makes the whole sample relationship negative.

Hence, this theory can explain both positive and negative relations between risk and return for the whole sample.

Table 2 shows the works that have tried to test Bowman's paradox through Prospect Theory with these two hypotheses: (1) low performers show a negative risk-return relationship, and (2) high performers show a positive riskreturn relationship. These studies divide the sample into two sub-samples - high and low performers - based on the return values and the target value. Therefore, if a firm's return is lower than the target value, it will be a low performer; otherwise, it will be a high performer. The selected target is usually some central measure of the return of the industry (e.g., the mean of the median of the industry returns).

Most empirical works [20,31,34-36] support the two hypotheses: low performers show a negative relationship between risk and return, and high performers show a positive relationship. Besides, Chang and Thomas [20] found a curvilinear relationship between risk and return, and Fiegenbaum [35] obtained that the low-performers' regression slope was steeper than the high performers, according to prospect theory hypothesis $[21$, p. 280$]$.

Though empirical tests support these hypotheses, some problems are evident:

1. Prospect theory describes the individual behavior but, in these tests, is used as a theory that describes organizational behavior.
2. There are some problems with the definition of the target level. Most researchers assume that the target level is the same for all firms in an industry, setting the industry average or median of returns as the target level. Nevertheless, prospect theory posits the status quo of a firm's performance and not the industry average as the reference point [39, p. 62]. Therefore, the reference point seems to be firm specific, and it can be an error to consider it common for all firms in the sample. This problem will be discussed further in behavioral theory.

3. Most of these studies are cross-sectional in design, so do not decisively reject the possibility that the variation in risk taking across organizations stems from established differences among them [58, p. 6]. Furthermore, the risk attitude can be considered firm specific, which makes the use of cross-sectional analyses inappropriate. As a solution, some authors have used firm-specific longitudinal models $[39,40]$, reaching similar results to cross-sectional works.

4. Finally, most of the studies have related the firm risk level to the performance level, while prospect theory links the risk attitude to the performance level. This treatment implicitly assumes that the risk experienced by the firm is the risk the decision maker desired [39, p. 62]. This assumption presents two problems: (a) it implies that the decision maker has perfect knowledge of performance in the future [39, p. 62], and (b) it is assumed that all the risk of the firm is a consequence of the decision maker's attitude. To avoid this problem, some authors have tried to measure the managerial risk attitude [32,41,39], finding support for prospect theory hypotheses.

\subsubsection{Behavioral theory}

Behavioral theory [22] is the second theory that explains the paradox from the attitude towards risk showed by the firms, and it leads to similar hypotheses to prospect theory.

With this focus, firms are described as large systems of standard operating procedures, where managers take decisions based on two different measures: the performance level they aspire to (aspirations), and the performance level they expect (expectations) [42, p. 39]. Thus, managers will differentiate between two kinds of outcomes: failures and success outcomes [43, p. 61]. The first ones will be those outcomes lower than the aspiration level, while the second will be those higher than the aspiration level.

According to this theory, the amount of risk managers will accept will depend on the expected performance in relation to the aspiration [43, p. 59]. When the expected performance is higher than the aspiration, managers consider that the firm is performing well, so no change is needed. If managers expect performance to fall below the aspiration level, creating a gap between aspirations and performance sufficient to create a sense of crisis, a major organizational change in the firm will be needed [44, p. 136] to find new procedures and techniques that increase the performance. This change 
Table 2

Focus on prospect theory

\begin{tabular}{|c|c|c|c|c|c|c|c|c|}
\hline \multirow[t]{2}{*}{ Researchers } & \multicolumn{3}{|l|}{ Measures } & \multicolumn{4}{|l|}{ Sample } & \multirow{2}{*}{$\frac{\text { Results }}{\text { Relationship }}$} \\
\hline & Return & Risk & Target & Firms & Industries & Source & Period & \\
\hline Bowman [31] & ROE & Content analysis & $\begin{array}{l}\text { Bottom quartile as low } \\
\text { performers, top quar- } \\
\text { tile as high performers }\end{array}$ & 155 & 3 & Value Line & 1979 & $\begin{array}{l}\text { Negative for firms, but not } \\
\text { significant for industries }\end{array}$ \\
\hline Bowman [32] & ROE & Content analysis & $\begin{array}{l}\text { Bottom quartile as low } \\
\text { performers, top quar- } \\
\text { tile as high performers }\end{array}$ & 26 & 1 & Value Line & 1972-1981 & $\begin{array}{l}\text { No risk influence on future } \\
\text { performance. Negative influ- } \\
\text { ence of performance on fu- } \\
\text { ture risk. Significant support } \\
\text { for prospect theory }\end{array}$ \\
\hline $\begin{array}{l}\text { Fiegenbaum and } \\
\text { Thomas [34] }\end{array}$ & ROE & ROE variance & $\begin{array}{l}\text { Median industry } \\
\text { ROE }\end{array}$ & 2322 & 47 & Compustat & 1960-1979 & $\begin{array}{l}\text { Positive for firms above the } \\
\text { target; negative for firms be- } \\
\text { low target. Significant support } \\
\text { for prospect theory }\end{array}$ \\
\hline $\begin{array}{l}\text { Chang and } \\
\text { Thomas [20] }\end{array}$ & $\mathrm{ROA}(\mathrm{ROA})^{2}$ & ROA variance & Not mentioned & 64 & $\begin{array}{l}\text { Not } \\
\text { mentioned }\end{array}$ & $\begin{array}{l}\text { Compustat I and II } \\
\text { Census of Manufac- } \\
\text { turing }\end{array}$ & $1977-1981$ & $\begin{array}{l}\text { Curvilinear risk-return rela- } \\
\text { tionship observed. Significant } \\
\text { support for prospect theory }\end{array}$ \\
\hline $\begin{array}{l}\text { Miller and } \\
\text { Bromiley [26] }\end{array}$ & ROE ROA & $\begin{array}{l}\text { Income variabi- } \\
\text { lity, market risk } \\
\text { and strategic risk }\end{array}$ & $\begin{array}{l}\text { Mean industry } \\
\text { ROE and ROA }\end{array}$ & 746526 & $\begin{array}{l}\text { Not } \\
\text { mentioned }\end{array}$ & $\begin{array}{l}\text { Compustat and } \\
\text { C.R.S.P. }\end{array}$ & $\begin{array}{l}1978-1982 \\
1983-1987\end{array}$ & $\begin{array}{l}\text { No suport for prospect theory } \\
\text { hypotheses }\end{array}$ \\
\hline Fiegenbaum [35] & ROA & ROA variance & $\begin{array}{l}\text { Median of industry } \\
\text { ROA }\end{array}$ & 3300 & 85 & Compustat & $1977-1984$ & $\begin{array}{l}\text { Positive for firms above the } \\
\text { target; negative for firms be- } \\
\text { low the target. Significant } \\
\text { support for prospect theory }\end{array}$ \\
\hline Jegers [36] & $\begin{array}{l}\text { ROE ROA cash } \\
\text { flow/ capital cash } \\
\text { flow plus interests } \\
\text { over assets }\end{array}$ & $\begin{array}{l}\text { Variance and coeffi- } \\
\text { cient of variation } \\
\text { of return measures }\end{array}$ & Median of industry & 3250 & 110 & $\begin{array}{l}\text { Belgium National } \\
\text { Bank }\end{array}$ & 1977-1982 & $\begin{array}{l}\text { Positive for firms above the } \\
\text { target; negative for firms be- } \\
\text { low the target. Significant } \\
\text { support for prospect theory }\end{array}$ \\
\hline Sinha [37] & ROA & $\begin{array}{l}\text { Standard deviation } \\
\text { of ROA }\end{array}$ & $\begin{array}{l}\text { Median return of } \\
\text { the industry }\end{array}$ & 341 & 14 & $\begin{array}{l}\text { Centre for Research } \\
\text { in Finance database } \\
\text { of the Annual Report } \\
\text { Record }\end{array}$ & $1977-1985$ & $\begin{array}{l}\text { Negative and significant be- } \\
\text { low median; weak and posi- } \\
\text { tive above the median }\end{array}$ \\
\hline $\begin{array}{l}\text { Gooding } \\
\text { et al. [38] }\end{array}$ & ROE & $\begin{array}{l}\text { Standard deviation } \\
\text { of ROE }\end{array}$ & $\begin{array}{l}\text { Obtained from } \\
\text { the minimal level } \\
\text { of risk }\end{array}$ & $\begin{array}{l}\text { Between } 1405 \\
\text { and } 5107\end{array}$ & $\begin{array}{l}\text { Between } \\
29 \text { and } 45\end{array}$ & Compustat & $\begin{array}{l}1970-1974 \\
1975-1979 \\
1980-1984 \\
1985-1989\end{array}$ & $\begin{array}{l}\text { Significant support for the } \\
\text { positive quadratic relation- } \\
\text { ship. Denies the fixed refer- } \\
\text { ence point }\end{array}$ \\
\hline Lee [39] & $\begin{array}{l}\text { ROE and } \\
\text { market share }\end{array}$ & Content analysis & $\begin{array}{l}\text { Previous year } \\
\text { performance }\end{array}$ & 6 & 1 & $\begin{array}{l}\text { Annual reports and } \\
\text { Compustat }\end{array}$ & $\begin{array}{l}\text { Different for } \\
\text { each firm }\end{array}$ & $\begin{array}{l}\text { Performance change has a } \\
\text { negative influence in risk }\end{array}$ \\
\hline Lehner [40] & ROE & $\begin{array}{l}\text { Absolute difference } \\
\text { between } \mathrm{ROE}_{\mathrm{t}} \text { and } \\
\mathrm{ROE}_{\mathrm{t}-1}\end{array}$ & $\begin{array}{l}\text { Identificated by the } \\
\text { minimal level of risk }\end{array}$ & 876 & 14 & Compustat & 1972-1991 & $\begin{array}{l}\text { Empirically, the relative posi- } \\
\text { tion to the reference level ex- } \\
\text { plains the risk-return relation- } \\
\text { ship better than the change in } \\
\text { enviromental conditions }\end{array}$ \\
\hline
\end{tabular}


involves risk for the firm, because the consequences of change are usually less well known than the consequences of the status quo [43, p. 58]. Finally, if no solution is found, managers will be forced to set lower aspirations.

By linking performance with profitability, behavioral theory generates two hypotheses: (1) low performers - those whose expectations fall below the aspiration level — will undertake a risky organizational change resulting in a negative influence of return over risk; (2) high performers those whose expectations are above the aspiration level do not increase risk, and, therefore, their risk-return relationship will be positive.

Table 3 shows the empirical research relating to the paradox under this focus. All of the studies obtained strong support for these hypotheses.

Although prospect theory and behavioral theory hypotheses relating to a risk-return relationship are similar, there are some differences: (1) behavioral theory makes postulates about the firm's behavior, while prospect theory studies individual behavior; (2) in behavioral theory, the risk-return relationship is defined not only by the attitude towards risk, but also by some firm characteristics - mainly, organizational slack. The role played by these slack resources needs to be more properly defined, as both theoretical hypotheses and the empirical results are contradictory.

These works present some common problems with prospect theory. The first is the definition of the target or reference point. Many authors [26,34-36] have used the median of the performance of the sector as the reference point, but the assumption of a common target point for all firms in the industry does not seem likely. Other works $[42,45,43,46]$ address this problem and use the previous performance as a target, especially for those firms that are above the median of the sector.

Theoretical works about reference points state that these points are influenced by the overall context of experience [30, p. 8], [40, p. 65]. Fiegenbaum, Hart and Schendel [49] propose that past, present and future performance, as well as internal and external reference dimensions, form a strategic reference point matrix. Moreover, the focus of attention can make one reference point dominate over others, explaining the differences in risk taking [40, p. 65]. This fact can explain the differences between two different theories: prospect theory and threat-rigidity theory [50]. This latter theory postulates that the lower the performance of a firm, the lower the risk assumed by its managers. This behavior could be the result of establishing the distress point as the reference point: the firm would be above the distress point, so the managers will not take risks that could end the firm. Therefore, the relationship could be caused by a different reference point instead of a different risk-return pattern [40, p. 65], [27, p. 477]. Finally, following these arguments, some authors have tried to find the reference point for a firm by identifying the level of minimal risk in the quadratic equation that relates performance and risk in behavioral and prospect theories $[38,40]$.
The second problem is the cross-sectional design. In the same manner as prospect theory's authors, scholars have used firm-specific longitudinal analysis to test behavioral theory, obtaining support for behavioral theory hypotheses [48].

Finally, Palmer and Wiseman [48] dealt with the differentiation between managerial risk taking and firm risk, measuring them separately. Their results also supported behavioral theory.

\subsection{Strategic position and competitive advantage}

The relationship between risk and return can arise from the different strategic positions of the firms. A good firm management could achieve not only higher return, but also lower risk. Thus, market power, consumer orientation, and diversification strategy can produce high performance-low risk investments [2, pp. 25,26].

Researchers have studied these differences from three basic points of view: firm diversification, market power, and the influence of previous risk over performance. Table 4 shows the works included in this group.

\subsubsection{Diversification strategy}

The theoretical relationship between risk and return at the firm level can depend on the product diversification strategy of the firm. Thus, firms that follow an unrelated diversification strategy would — in theory — face a relatively low risk level because the relation among its businesses is low. Then, the covariance among these businesses' returns is near to zero or negative, reducing the whole firm's risk [23, p. 257, 20, p. 273]. Its expected return will be low too, because the weak relations among the business units do not allow them to reach synergies or share resources. Besides, the most common method for achieving an unrelated diversification pattern is by buying businesses in the market, which means that the assets of these businesses are highly priced. Return calculated on this high base will therefore be lower [23, p. 257, 20, p. 273]. Hence, these firms present a theoretical positive relationship between risk and return: a high variance business (high risk business) will be bought only if the expected return is also high.

Firms with related diversification will achieve a different risk-return pattern. The relationships among the businesses of the firm will theoretically involve greater risk because of the high correlation. Nevertheless, expected return will also be high, because such relationships will allow synergies among the business units. This diversification pattern is commonly achieved by developing the business into the firm, so assets will be priced lower than they would be if the business were bought in the market [23, p. 258]. The possibility of sharing managers' skills among related businesses can affect risk as well as return. Sharing manager skills and resources can lead to a lower risk for the firm. Hence, the relationship between risk and return would be less clear from this diversification pattern. 
Table 3

Focus on behavioral theory

\begin{tabular}{|c|c|c|c|c|c|c|c|c|c|}
\hline \multirow[t]{2}{*}{ Researchers } & \multicolumn{4}{|l|}{ Measures } & \multicolumn{4}{|l|}{ Sample } & \multirow{2}{*}{$\frac{\text { Results }}{\text { Relationship }}$} \\
\hline & Return & Risk & $\begin{array}{l}\text { Expectations and } \\
\text { aspirations }\end{array}$ & Slack & Firms & Industries & Source & Period & \\
\hline Singh [41] & $\begin{array}{l}\text { ROE, ROA } \\
\text { subjective in- } \\
\text { dex }\end{array}$ & Subjective index & & $\begin{array}{l}\text { Absorbed slack: } \\
\text { selling, general } \\
\text { and administra- } \\
\text { tive expenses and } \\
\text { working capital to } \\
\text { sales; unabsorbed } \\
\text { slack: cash over } \\
\text { current liabilities }\end{array}$ & 64 & $\begin{array}{l}\text { Not } \\
\text { mentioned }\end{array}$ & $\begin{array}{l}\text { Khandwalla's ques- } \\
\text { tionnaire, Moody's } \\
\text { industrial, transporta- } \\
\text { tion, public utility } \\
\text { and OTC industrial } \\
\text { manuals }\end{array}$ & $\begin{array}{l}1973- \\
1975\end{array}$ & $\begin{array}{l}\text { Direct negative be- } \\
\text { tween risk and return; } \\
\text { significant support for } \\
\text { behavioral theory }\end{array}$ \\
\hline Bormiley [42] & $\begin{array}{l}\text { ROE, ROA, } \\
\text { Return on } \\
\text { sales }\end{array}$ & $\begin{array}{l}\text { Variances of fore- } \\
\text { casted earnings }\end{array}$ & $\begin{array}{l}\text { Expectations by } \\
\text { the mean of earn- } \\
\text { ings forecast; as- } \\
\text { pirations based on } \\
\text { past performance } \\
\text { and industy mean }\end{array}$ & $\begin{array}{l}\text { Current ratio, } \\
\text { SG\&A over sales, } \\
\text { debt to equity, } \\
\text { interest coverage } \\
\text { ratio }\end{array}$ & 288 & $\begin{array}{l}\text { Not } \\
\text { mentioned }\end{array}$ & Compustat and IBES & $\begin{array}{l}1976- \\
1987\end{array}$ & $\begin{array}{l}\text { Negative between risk } \\
\text { and return; significant } \\
\text { support for behavioral } \\
\text { theory }\end{array}$ \\
\hline $\begin{array}{l}\text { Miller and } \\
\text { Leiblein [45] }\end{array}$ & ROE, ROA & $\begin{array}{l}\text { Standard deviation } \\
\text { and first and sec- } \\
\text { ond order low mo- } \\
\text { mentums }\end{array}$ & $\begin{array}{l}\text { Aspirations based } \\
\text { on previous per- } \\
\text { formance, average } \\
\text { performance of } \\
\text { the industry and } \\
\text { loss aversion }\end{array}$ & $\begin{array}{l}\text { Accounts receiv- } \\
\text { able over sales; } \\
\text { inventories over } \\
\text { sales; SG\&A over } \\
\text { sales }\end{array}$ & $\begin{array}{l}\text { Not } \\
\text { mentioned }\end{array}$ & $\begin{array}{l}\text { Not } \\
\text { mentioned }\end{array}$ & Compustat & $\begin{array}{l}1971- \\
1991\end{array}$ & $\begin{array}{l}\text { More statistical sig- } \\
\text { nificance with parrtial } \\
\text { moments. Positive in- } \\
\text { fluence of risk on re- } \\
\text { turn and negative of } \\
\text { return on risk; signif- } \\
\text { icant support for be- } \\
\text { havioral theory }\end{array}$ \\
\hline $\begin{array}{l}\text { Wiseman and } \\
\text { Bromiley [46] }\end{array}$ & $\begin{array}{l}\text { ROE, ROA } \\
\text { and Return on } \\
\text { sales }\end{array}$ & $\begin{array}{l}\text { Variance of fore- } \\
\text { casted incomes }\end{array}$ & $\begin{array}{l}\text { Aspirations based } \\
\text { on the industry av- } \\
\text { erage performance } \\
\text { for low perform- } \\
\text { ers and on the pre- } \\
\text { vious performance }\end{array}$ & $\begin{array}{l}\text { Current ratio, } \\
\text { SG\&A over sales, } \\
\text { debt to equity } \\
\text { ratio and interest } \\
\text { coverage ratio }\end{array}$ & 323 & $\begin{array}{l}\text { Food } \\
\text { processing and } \\
\text { manufacturing } \\
\text { industries }\end{array}$ & Compustat and IBES & $\begin{array}{l}1975- \\
1988\end{array}$ & $\begin{array}{l}\text { Organizational } \\
\text { decline increases } \\
\text { risk-taking; risk tak- } \\
\text { ing reduces subse- } \\
\text { quent performance }\end{array}$ \\
\hline
\end{tabular}




\begin{tabular}{|c|c|c|c|c|c|c|c|c|c|}
\hline $\begin{array}{l}\text { Wiseman and } \\
\text { Catanach [47] }\end{array}$ & $\begin{array}{l}\text { Operating cash } \\
\text { flow to total } \\
\text { assets }\end{array}$ & $\begin{array}{l}\text { Realized credit } \\
\text { risk, realized } \\
\text { interest-rate risk } \\
\text { and realized } \\
\text { liquidity risk }\end{array}$ & Not mentioned & $\begin{array}{l}\text { SG\&A to assets } \\
\text { SG\&A to assets }\end{array}$ & $\begin{array}{l}\text { From } 3544 \\
\text { to } 2586\end{array}$ & 1 & $\begin{array}{l}\text { Department of Labor } \\
\text { Statistics and Thrift } \\
\text { Financial Reports }\end{array}$ & $\begin{array}{l}1979- \\
1988\end{array}$ & $\begin{array}{l}\text { Support for behav- } \\
\text { ioral hypotheses even } \\
\text { when agency-based } \\
\text { influences are con- } \\
\text { trolled for }\end{array}$ \\
\hline Greve [43] & $\begin{array}{l}\text { Audience } \\
\text { share }\end{array}$ & $\begin{array}{l}\text { Organizational } \\
\text { changes }\end{array}$ & $\begin{array}{l}\text { Aspirations based } \\
\text { on previous per- } \\
\text { formance and av- } \\
\text { erage of the per- } \\
\text { formance of the } \\
\text { industry }\end{array}$ & & 160 & 1 & Arbitron & $\begin{array}{l}1984- \\
1992\end{array}$ & $\begin{array}{l}\text { High performance } \\
\text { reduces the change } \\
\text { likelihood; significant } \\
\text { support for behavioral } \\
\text { theory }\end{array}$ \\
\hline $\begin{array}{l}\text { Palmer and } \\
\text { Wiseman [48] }\end{array}$ & ROA and ROE & $\begin{array}{l}\text { Variance in ROA, } \\
\text { Variance in PER, } \\
\text { R\&D expendi- } \\
\text { ture, diversifica- } \\
\text { tion indicators }\end{array}$ & $\begin{array}{l}\text { Aspirations based } \\
\text { on the average re- } \\
\text { turn of the indus- } \\
\text { try for low per- } \\
\text { formers; based on } \\
\text { the previous re- } \\
\text { turns for high per- } \\
\text { formers }\end{array}$ & $\begin{array}{l}\text { Quick ratio, } \\
\text { administrative } \\
\text { and operational } \\
\text { expenses to } \\
\text { sales, debt to } \\
\text { equity ratio }\end{array}$ & 235 & 64 & Compustat & $\begin{array}{l}1984- \\
1991\end{array}$ & $\begin{array}{l}\text { Support for behavioral } \\
\text { explanation of risk }\end{array}$ \\
\hline $\begin{array}{l}\text { Deephouse } \\
\text { and Wiseman } \\
{[27]}\end{array}$ & ROA & $\begin{array}{l}\text { Variance of } \\
\text { forecasted } \\
\text { incomes }\end{array}$ & $\begin{array}{l}\text { Expectations us- } \\
\text { ing the average } \\
\text { forecast of earn- } \\
\text { ings per share; as- } \\
\text { pirations using the } \\
\text { greater of industry } \\
\text { average return for } \\
\text { the prior year or } \\
\text { the firm's actual } \\
\text { return in the prior } \\
\text { year plus a five } \\
\text { percent growth } \\
\text { factor }\end{array}$ & $\begin{array}{l}\text { Current ratio } \\
\text { SG\&A on sales } \\
\text { Debt to } \\
\text { equity ratio }\end{array}$ & $\begin{array}{l}367 \text { and } \\
695\end{array}$ & & $\begin{array}{l}\text { Compustat } \\
\text { and IBES }\end{array}$ & $\begin{array}{l}1973- \\
1977 \\
1978- \\
1982 \\
1983- \\
1987\end{array}$ & $\begin{array}{l}\text { Significant support } \\
\text { for behavioral the- } \\
\text { ory. Weak support } \\
\text { for Agency Theory. } \\
\text { Strong influence of } \\
\text { the economic envi- } \\
\text { ronment on the } \\
\text { risk-return relation }\end{array}$ \\
\hline
\end{tabular}


Table 4

Focus on strategic position

\begin{tabular}{|c|c|c|c|c|c|c|c|c|}
\hline \multirow{3}{*}{$\begin{array}{l}\text { Researchers } \\
\text { Bettis and } \\
\text { Hall [23] }\end{array}$} & \multirow{3}{*}{$\begin{array}{l}\text { Theory } \\
\text { Diversification }\end{array}$} & \multicolumn{2}{|l|}{ Measures } & \multicolumn{4}{|l|}{ Sample } & \multirow{2}{*}{$\frac{\text { Results }}{\text { Relationship }}$} \\
\hline & & Return & Risk & Firms & Industries & Source & Period & \\
\hline & & ROA & $\begin{array}{l}\text { Standard deviation } \\
\text { of ROA }\end{array}$ & 80 & Not mentioned & Compustat & 1973-1977 & $\begin{array}{l}\text { Positive association for non } \\
\text { related diversification strategy } \\
\text { firms; negative association for re- } \\
\text { lated diversification }\end{array}$ \\
\hline $\begin{array}{l}\text { Bettis and } \\
\text { Mahajan [24] }\end{array}$ & Diversification & $\mathrm{ROA}$ & $\begin{array}{l}\text { Standard deviation } \\
\text { of ROA }\end{array}$ & 80 & Not mentioned & Compustat & 1973-1977 & $\begin{array}{l}\text { Related diversification firms are } \\
\text { in negative relation cluster; } \\
\text { non-related are in positive rela- } \\
\text { tion clusters }\end{array}$ \\
\hline $\begin{array}{l}\text { Amit and } \\
\text { Livnat }[51]\end{array}$ & Diversification & $\begin{array}{l}\text { Funds from opera- } \\
\text { tions over assets }\end{array}$ & $\begin{array}{l}\text { Standard deviation } \\
\text { of return }\end{array}$ & 400 & Not mentioned & Compustat & 1977-1984 & $\begin{array}{l}\text { Most of the firms show positive } \\
\text { relationship. No support for the } \\
\text { Paradox }\end{array}$ \\
\hline $\begin{array}{l}\text { Chang and } \\
\text { Thomas [20] }\end{array}$ & Diversification & $\mathrm{ROA}$ and $\mathrm{ROA}^{2}$ & ROA variance & 64 & Not mentioned & $\begin{array}{l}\text { Compustat I } \\
\text { and II }\end{array}$ & 1977-1981 & $\begin{array}{l}\text { No impact of diversification on } \\
\text { strategic risk }\end{array}$ \\
\hline Cool et al. [25] & Market power & $\begin{array}{l}\text { ROA, return on } \\
\text { sales, average re- } \\
\text { turn on assets }\end{array}$ & $\begin{array}{l}\text { Standard deviation } \\
\text { of return measures }\end{array}$ & 21 & 1 & $\begin{array}{l}\text { Census of } \\
\text { Manufacturing } \\
\text { Indiana Banks }\end{array}$ & $1975-1979$ & $\begin{array}{l}\text { Positive between risk and re- } \\
\text { turn, negative between market } \\
\text { share and return, negative be- } \\
\text { tween market share and risk }\end{array}$ \\
\hline $\begin{array}{l}\text { Miller and } \\
\text { Bromiley [26] }\end{array}$ & $\begin{array}{l}\text { Adjustment costs } \\
\text { and default risk }\end{array}$ & $\mathrm{ROE}$ and ROA & $\begin{array}{l}\text { Measures from } \\
\text { factorial analysis; } \\
\text { income variability, } \\
\text { market risk and } \\
\text { strategic risk }\end{array}$ & 526746 & Not mentioned & $\begin{array}{l}\text { Compustat and } \\
\text { CRSP }\end{array}$ & $\begin{array}{l}1978-1982 \\
1983-1987\end{array}$ & $\begin{array}{l}\text { Support for the negative influence } \\
\text { of risk over subsequent return }\end{array}$ \\
\hline Kim et al. [52] & Diversification & Industry ROA & $\begin{array}{l}\text { Industry standard } \\
\text { deviation of ROA }\end{array}$ & 125 & Not mentioned & Compustat & 1982-1986 & $\begin{array}{l}\text { Global market diversification in- } \\
\text { creases returns and reduces risk; } \\
\text { risk-return trade off found for } \\
\text { product diversification }\end{array}$ \\
\hline
\end{tabular}


Despite these theoretical relations, the empirical tests of these hypotheses do not strongly support them. Related firms achieved, on average, higher return at a lower risk, but there was no causal relationship between diversification strategy and risk-return relationship [23,24]. Product diversification seems to have little impact on the negative risk-return relation [20,52] or no influence at all [51].

Kim et al. [52] found a positive relationship between multinational diversification and return, as well as a negative relation between multinational diversification and risk. They concluded that, once the industry effect is controlled, multinational diversification can produce the Bowman's paradox.

\subsubsection{Market power}

Another factor that can influence the risk-return relationship is the market power of the firm. The theoretical link between market power and return has been considered positive, for reasons such as brand fidelity, economies of scale, experience curve effects, and greater bargaining power with suppliers and distributors [53, p. 149]. A high market power firm could also get lower risk because firms with greater market power can pass their risk on to customers or suppliers [53, p. 151] instead of their stockholders.

Market power has been directly related to return and inversely related to risk, so it may be considered one of the possible causes of Bowman's paradox. However, empirical results do not sufficiently support the former explanation. Several works acknowledge the positive relationship between return and market power, but, as Woo [53, p. 149] points out, other studies have also acknowledged insignificant relationships after third factors common to both variables have been removed. Concerning the market power-risk relation, Woo [53] shows that it was dependent on the risk measure used and the industry selected. The results for accounting risk (ROA variance) were not significant in this study.

When Cool et al. [25] tested the relationship between return, risk and market power, their results supported the former hypotheses: market power is positively related to return and inversely related to risk. However, they also found a direct relationship between risk and return.

In brief, these ambiguous results indicate that the role of market power has not been thoroughly tested empirically. Hence, research on this area should continue.

\subsubsection{The impact of previous risk on return}

The main focus of scholars who have studied Bowman's paradox has been the influence of the expected return on the managerial risk taking. This is the focus employed in those works that use prospect or behavioral theories as background. Nevertheless, the risk level can also influence the performance level of a firm. Two arguments support this risk influence on the latter return: default risk and adjustment costs.

The first argues that variability in performance increases a firm's default risk, because this variability also increases the likelihood that a firm will default on its explicit or implicit commitments. Hence, customers, suppliers and employees will require a monetary incentive to induce them into a transaction [26, p. 766]. The adjustment costs argument says that high variability in sales makes efficient utilization of capital difficult, and hence increases costs [26, p. 767].

This focus has been little employed to date, but its hypotheses have been significantly supported. For example, Miller and Bromiley [26] found that their data supported this focus instead of Prospect theory hypotheses. Similar results were achieved by Bromiley [42], although this study was based on behavioral theory [22]. Deephouse and Wiseman [27] and Veliyath and Ferris [14] also employed the default risk argument as a theoretical background, finding a negative influence of risk on the latter return.

Finally, Miller and Leiblein [45] studied the influence of risk on subsequent performance, finding a positive influence of the first on the latter, contrary to default risk hypothesis. The explanation is that they tested the influence on the long run, while Bromiley [42] studied the influence on a shorter period of time.

\section{Criticisms of the methodology in organization theory}

Some scholars point out that Bowman's paradox can only be the result of some methodological mistake that biases the real relationship between risk and return. We now survey works grouped into three categories of criticisms: statistical measures, sample and accounting data reliability. These works are shown in Table 5.

\subsection{Statistical measures}

Most criticisms of Bowman's paradox studies have focused on the statistical measures used in the research. Bowman's paradox is centered on the relationship between the accounting variables of return and risk. Hence, most articles have used accounting ratios to measure them. For example, to measure return, researchers have mainly employed the average of ROA, ROE, or profit over sales. The main risk measures have been the variances of the return variables, though some researchers have used other measures, as analysts forecast variance, $\mathrm{R} \& \mathrm{D}$ cost or advertising cost.

Criticisms have been made about both expected return and risk measures, although the latter have been more important. The first problem is caused by cross-sectional analysis. Thus, using this methodology, the risk is measured ex-post, but not ex-ante [2, p. 18], [9, p. 168]. Some scholars have tried to avoid this problem by using lagged models $[45,32,42]$ to prove causal relationships between risk and return from different periods, or employing ex-ante measures of risk, such as the variability of earnings forecasts [42], questionnaire information [41], or the risk aversion coefficient obtained from a theoretical utility function [62]. 
Table 5

Empirical criticisms to Bowman's paradox works

\begin{tabular}{|c|c|c|c|c|c|c|c|c|}
\hline \multirow[t]{2}{*}{ Researchers } & \multirow[t]{2}{*}{ Criticisms } & \multicolumn{2}{|l|}{ Measures } & \multicolumn{4}{|l|}{ Sample } & \multirow{2}{*}{$\frac{\text { Results }}{\text { Relationship }}$} \\
\hline & & Return & Risk & Firms & Industries & Source & Period & \\
\hline $\begin{array}{l}\text { Marsh and } \\
\text { Swanson [54] }\end{array}$ & Statistical measures & Transformed ROE & $\begin{array}{l}\text { Variance of } \\
\text { transformed ROE }\end{array}$ & 175 & 10 & $\begin{array}{l}\text { Ross Watts and } \\
\text { Value Line }\end{array}$ & $1958-1981$ & $\begin{array}{l}\text { Both relationships, but } \\
\text { most of them are not } \\
\text { significant }\end{array}$ \\
\hline $\begin{array}{l}\text { Fiegenbaum and } \\
\text { Thomas [55] }\end{array}$ & Temporal stability & ROE & ROE variance & $\begin{array}{l}\text { Between } 345 \\
\text { and } 700\end{array}$ & 7 & $\begin{array}{l}\text { Value Line and } \\
\text { Compustat }\end{array}$ & $\begin{array}{l}1960- \\
1979\end{array}$ & $\begin{array}{l}\text { Negative on } 1970 \mathrm{~s} \\
\text { and positive on } 1960 \mathrm{~s}\end{array}$ \\
\hline $\begin{array}{l}\text { Fiegenbaum and } \\
\text { Thomas [13] }\end{array}$ & $\begin{array}{l}\text { Temporal stability, } \\
\text { market risk }\end{array}$ & ROE & $\begin{array}{l}\text { ROE variance and } \\
\text { CAPM beta }\end{array}$ & $\begin{array}{l}\text { Between } 1283 \\
\text { and } 2394\end{array}$ & 35 to 76 & Compustat & $\begin{array}{l}1960- \\
1979\end{array}$ & $\begin{array}{l}\text { Negative on 1970s } \\
\text { and positive on 1960s; } \\
\text { not significant with } \\
\text { market measures }\end{array}$ \\
\hline $\begin{array}{l}\text { Aaker and } \\
\text { Jacobson [56] }\end{array}$ & Statistical measures & ROI & $\begin{array}{l}\text { Systematic and } \\
\text { unsystematic risk }\end{array}$ & $\begin{array}{l}1376 \\
\text { businesses }\end{array}$ & $\begin{array}{l}\text { Not } \\
\text { mentioned }\end{array}$ & PIMS & $\begin{array}{l}\text { Not } \\
\text { mentioned }\end{array}$ & $\begin{array}{llr}\text { Positive } & \text { correlation } \\
\text { between both risks } \\
\text { and ROI }\end{array}$ \\
\hline $\begin{array}{l}\text { Fiegenbaum and } \\
\text { Thomas [57] }\end{array}$ & $\begin{array}{l}\text { Temporal stability, } \\
\text { statistical measures }\end{array}$ & $\begin{array}{l}\mathrm{ROE} \text {, debt to } \\
\text { assets, current } \\
\text { ratio, sales to as- } \\
\text { sets }\end{array}$ & Variance of returns & $\begin{array}{l}\text { Not } \\
\text { mentioned }\end{array}$ & 9 & Compustat & $1972-1980$ & $\begin{array}{l}\text { Negative for stock- } \\
\text { holders and bondhold- } \\
\text { ers; overall support for } \\
\text { the paradox }\end{array}$ \\
\hline $\begin{array}{l}\text { Oviatt and } \\
\text { Bauerschmidt [58] }\end{array}$ & Statistical measures & $\begin{array}{l}\text { Logarithm of } \\
\text { ROE }\end{array}$ & $\begin{array}{l}\text { Deviation of return } \\
\text { measure from a } \\
\text { trend line }\end{array}$ & 141 & 8 & $\begin{array}{l}\text { Standard and Poor } \\
\text { stock report }\end{array}$ & $\begin{array}{l}1970- \\
1979\end{array}$ & $\begin{array}{l}\text { Negative using OLS; } \\
\text { positive using SLS }\end{array}$ \\
\hline $\begin{array}{l}\text { Wiseman and } \\
\text { Bromiley [59] }\end{array}$ & Statistical measures & $\mathrm{ROE}$ and ROA & $\begin{array}{l}\text { ROE and ROA } \\
\text { variances and sum } \\
\text { of quadratic errors } \\
\text { from a trend line }\end{array}$ & 2179 & 57 & Compustat & $1968-1987$ & $\begin{array}{l}\text { No difference between } \\
\text { both risk measures }\end{array}$ \\
\hline $\begin{array}{l}\text { Collins and } \\
\text { Ruefli [60] }\end{array}$ & Statistical measures & ROA & Ordinal risk measure & 27 & 1 & Not mentioned & $1968-1985$ & Negative \\
\hline $\begin{array}{l}\text { Baucus } \\
\text { et al. [61] }\end{array}$ & $\begin{array}{l}\text { Statistical measures, } \\
\text { temporal stability }\end{array}$ & $\begin{array}{l}\text { ROA measured at } \\
\text { the end of the pe- } \\
\text { riod (EOP) and at } \\
\text { the beginning of } \\
\text { the period (BOP) }\end{array}$ & $\begin{array}{l}\text { Standard deviations } \\
\text { of return measures }\end{array}$ & 1005 & 35 & Compustat & $\begin{array}{l}1969- \\
1988\end{array}$ & $\begin{array}{l}\text { EOP measures tend to } \\
\text { negative; BOP mea- } \\
\text { sures tend to positive; } \\
\text { no stable relationship }\end{array}$ \\
\hline $\begin{array}{l}\text { Walls and } \\
\text { Dyer [62] }\end{array}$ & Statistical measures & ROA & $\begin{array}{l}\text { Risk tolerance } \\
\text { ratio }\end{array}$ & 55 & 1 & $\begin{array}{l}\text { Oil and Gas } \\
\text { Journal Energy } \\
\text { Database }\end{array}$ & $1983-1990$ & $\begin{array}{l}\text { Substantial differences } \\
\text { between ex-ante and } \\
\text { ex-post measures of } \\
\text { risk }\end{array}$ \\
\hline $\begin{array}{l}\text { McNamara and } \\
\text { Bromiley [8] }\end{array}$ & Statistical measures & $\begin{array}{l}\text { Average } \\
\text { interest rate } \\
\text { charged and risk- } \\
\text { adjusted return }\end{array}$ & $\begin{array}{l}\text { Lender's } \\
\text { perceptions }\end{array}$ & 1 & 1 & $\begin{array}{l}\text { Evaluations made } \\
\text { in a banking } \\
\text { division }\end{array}$ & & $\begin{array}{l}\text { Positive relationship } \\
\text { when expected re- } \\
\text { turns are measured } \\
\text { by interest rate; } \\
\text { negative when they } \\
\text { are measured with } \\
\text { risk-adjusted returns }\end{array}$ \\
\hline
\end{tabular}


The key problem concerning the study of risk is the use of the variance. Although widely used by researchers as a measure of risk, there is no theory linked to it [9, p. 168]. It is questionable that the "strategic risk" could be properly measured by the simple variance, as "risk" is a very complex concept. Therefore, the paradox could be not a real relationship between risk and return, but a mean-variance relationship, where the variance is a bad indicator for risk [45,56,63-65].

The theoretical discussion of variance as a risk indicator has adopted two main postures. First, it seems that managers do not use the variance when they make their decisions because they are not used to the distributions of probability of the variables [64], or because they consider only the negative variations "risky", not the positive ones [45,9, p. 178]. Following this argument, when Miller and Leiblein [45] tested the relationship using measures of downside risk they obtained support for Behavioral Theory hypotheses.

Second, contrary to the former line of thought, managers could use variance and additional information in their risk measuring. Other dimensions of strategic risk have been acknowledged, such as the failure risk - the probability of not reaching a target point - [65-67], the ruin risk - the probability of ruinous loss - [65-67], the size of loss $[64,66]$, the lack of information [66], and the innovation level of the firm $[31,32,66]$. In addition, managers should take into account the risk for all the stakeholders of the firm [57]. Miller and Bromiley [26] used various risk measures in a factor analysis, obtaining three factors for risk measure: income variability, market risk, and strategic risk. Their analyses obtained a negative influence of risk on subsequent return.

In summary, if variance is not used by managers as a measure of risk, or if it is insufficient for measuring it, the mean-variance relationship cannot be assimilated into the real risk-return relationship. Nevertheless, the empirical works that have tested the paradox using risk measures different from the variance of the performance have provided significant support for the paradox hypotheses [45,31] similar to the variance.

A third criticism of variance is that this measure can bias the results if used on a sample whose results are part of a trend. Thus, firms in an industry whose sales are growing or declining would have higher variances and, hence, higher estimated risk. Nevertheless, the relationship between return and risk measured with the errors on a regression line has been tested, and the results do not differ significantly from the variance studies $[58,59]$.

The last criticism of risk is the possible statistical relationship between the mean and the variance of the same variable. By measuring return as the average of profitability, and risk as a variance of profitability, we are relating two moments of the same random variable. The relationship between risk and return could be only a statistical relationship between those two moments, not a real economic relationship between risk and return. One of the most common hypotheses to avoid this problem is to consider that firm profitability is normally distributed, and then mean and variance are not statistically related. However, accounting ratio distributions studies show that these variables are not normally distributed, and their probability distributions are similar to log-normal or gamma distributions [54, p. 37]. Thus, mean and variance would be statistically related by the distribution of the random variable.

Another problem with the mean-variance relationship is its dependence on the aggregation period chosen [68-70]. Thus, a negative relationship in a period $T$ could be obtained from positive relationships in sub-periods of $T$ [68]. Hence, the mean-variance approach would not be useful in determining the real relationship between risk and return, as any relationship can be caused by relationships of any sign in lower periods or can cause any sign relationships in higher periods.

The stability of the profitability distribution is also a key issue in the empirical research [68, p. 371] because the relationship between profitability and time can be the result of elements drawn from a single risk-return relationship or from various mean-variance relationships caused by different profitability distributions throughout time. Since estimations of variance and mean are meaningful only for stationary time-series of returns [40, p. 63], an initial hypothesis should be the stability of the return distribution, although this hypothesis is questionable for the analysis of long time-periods [71, p. 208].

To avoid the effects of non-stationary time-series, the period analyzed by the researchers has been relatively short (five-year periods) [40, p. 67], but this short period makes the influence of extreme observations greater, which can produce similar results to Prospect Theory or Behavioral theory hypotheses. Let us consider a firm with expected return $M$ and variance $V$ for the five-year period. Let us assume that, in one of the five years, the firm obtains an extremely low (high) result. If we try to measure $M$ and $V$ using the five observations, the extreme observation will imply a higher variance and a lower (higher) expectation. The result is the same as that predicted by Prospect and Behavioral theories: if a firm obtains an extremely low value, its mean will be low (below the target) and its variance will be high, that is to say, low return and high variance; on the other hand, if the extreme value is high, the mean will also be high (above the target) and the variance will be high as well, that is to say, high return and high variance. In summary, the negative relationship below the reference point or the positive relationship above it can be simply produced by firms with extremely low or extremely high observations.

Return measures have been questioned less than risk measures although the accounting ratios of profitability present some defects that bring into question their quality as indicators of return: they relate the earnings of the period with investments or net worth, but these denominators can also influence future earnings [56, p. 283].

The main criticism of the profitability measure is based on the measurement of the denominator of the ratio at the end 
of the period [61]. Accounting ratios such as ROE or ROA, which use end of the period (EOP) measures - book value or total assets measured at the end of the period - have been used in almost all the empirical studies. This fact tends to present a negative relationship between profitability ratio and its variance: firms that have achieved an extraordinarily high profit - high return - increase book value too. If we use this variable at the end of the period, the denominator of the ratio will be higher, and therefore, the ratio itself and its variance will be lower. If the firm obtained high losses - low return - the book value measured at the end of the period will be lower and, hence, the ratio and its variance will be higher [61, p. 390].

\subsection{Sample criticisms}

One of the methodological problems researchers have to confront is the sample selection. In the first place, it is possible that the relationship found by Bowman was only a short-term relationship, being a real positive correlation between risk and return in the long term as the financial economic theory states [2, p. 27]. This idea led researchers to employ samples from diverse time periods to study the stability of the negative relationship, and find both negative and positive relationships depending on the period of time chosen $[55,13]$. Despite this, no longitudinal study has examined this temporal instability.

Another problem related to sample selection is the industry classification. It has been demonstrated that the industry effect on the risk-return pattern is very important [45, p. 99]. Thus, features like concentration degree, and position in life cycle are key variables in the relationship between risk and return of the firms $[2$, p. 27,13 , p. 400].

\section{Conclusions and future research}

Although many works provide evidence of the negative relationship between the accounting measures of risk and return, none are free from criticism because they have not resolved all their problems at the same time. The correct measure of "risk", the stability of the relationship, or the cross-sectional design of the research are weak points of nearly all the works that have been overcome independently.

Nevertheless, it can be said that investigation in this area is progressing, mainly in the area of risk measures. In this sense, the literature has proved that the traditional variability measures - the variance and its derivatives - present important methodological problems in relation to the mean of the variable. Perhaps the strongest criticisms are that there are problems of identification because mean and variance come from the same variable, and that the variance is measured ex-post (historical) when it should be ex-ante (expectation) [9]. Although there is no methodological solution in the papers on Bowman's paradox to date, both problems can be solved using GARCH models, in which mean and vari- ance are defined by different equations. Besides solving the problem of identification, this model can estimate forward variances equal to the mean. Nevertheless, for accounting data, it is necessary to recognize that we could find a restriction in relation to the small number of observations. The solution applied to this problem is the search for new measures of risk, different from the traditional variance or variance-related measures. Some examples of the new kind of risk measures could be downsize measures [45], ordinal risk measures [60], content analysis measured risk [32,39], the mean of the quadratic changes in performance [40], or the variance of forecasted incomes [42,46,27]. Another focus has been the direct measure of the manager's risk perception, using questionnaires $[41,47,8]$. Finally, some authors use proxies for measuring managerial risk taking, such as the $R \& D$ expenditure or debt to equity ratio $[26,48]$. The results achieved when these new measures are used often show a negative relationship between risk and return, supporting the hypothesis from the paradox, if other criticisms are not considered. Nevertheless, these measures are still rarely studied, and have their own problems. Therefore, research of more suitable ways for measuring risk is vital for the development of this stream of investigation [9].

As we mentioned in the introduction, from Fama and French [1], the theoretical positive relationship between risk (beta) and return at the market level has been challenged. Several authors have tried to demonstrate that the death of beta has been exaggerated $[4,5]$ because there still exists a positive relationship between beta and return; other authors support the result found by Fama and French [1], proving that there is no correlation between beta and returns [11]; and finally, other authors have stated that the relationship between both measures depends on the situation of the market expected return, above or below the risk-free return $[3,6]$. It is amazing how this evolution in financial economics theory is almost identical to the evolution of Bowman's paradox, although it is surprising that there is no mention in these financial works to the previous Bowman's paradox literature.

In this sense, some financial authors are starting the search for new measures of risk that substitute or complement the beta from the CAPM [12]. Between these new measures, the accounting measures have the most relevant position.

We think that these two research lines that to date have been mutually ignored, with the exceptions of Fiegenbaum and Thomas [13], Veliyath and Ferris [14], Chatterjee et al. [15], and Ruefli et al. [9], should be integrated in a wider frame for researching the relationship between risk and return.

This inter-disciplinary focus must also be extended towards accounting research, since most of the measures used in Bowman's paradox, and the new risk measures for the financial works, come from the accounting information. The development of reliable methods of measuring accounting risk is vital for the progress of this line of research.

Finally, the inter-disciplinary focus is necessary for researching some lags in Bowman's paradox. In this sense, we 
mention the reliability of the accounting measures, since a common criticism of accounting information research is the relative reliability of these measures. Accounting scholars have demonstrated that some accounting practices, known as "earnings management", can influence reported income, presenting a distorted picture of firm performance. Bowman [2, p. 25] pointed out that the paradox could be only the result of these practices among the high-performing firms. Although various works have tested Bowman's paradox hypotheses using measures different from accounting indicators $[42,46,27,41,47,8]$, or accounting measures less susceptible to manipulation [36], to date no study has tested the possible effect of earnings management practices on the risk-return relationship. In this sense, it is interesting to observe how prospect theory has been employed to explain both Bowman's paradox and earnings management $[72,73]$.

A second lag in Bowman's paradox literature is the so-called "masking effect" of the market, that is, how the accounting risk-return relationship influences the market relation. Scholars have hardly studied this issue, and their results are contradictory. In his first work, Bowman [2] hypothesized that the market could mask the paradox through the price mechanism. On one hand, those firms with high accounting returns and low variance would be highly priced at the market, which would produce lower rates of return and risk. On the other hand, firms with low accounting returns and high variance would be lowly priced at the market, and this price would allow higher returns and variability. This "masking effect" was tested by Fiegenbaum and Thomas [13] by relating the accounting return with a market risk measure (this measure was the beta parameter from the CAPM). They found a significant positive relationship between beta and accounting return and, based on this result, concluded that the market masked the paradox. Nevertheless, there is a contradiction between Bowman's argument [2] and Fiegenbaum and Thomas' results [13]: while Bowman's argument implies a negative relationship between accounting return and both market measures (high accounting returns imply high price and hence, low market risk and return) and a positive relationship between accounting risk and market measures (the higher the accounting risk, the lower the price and hence, the higher market return and risk), Fiegenbaum and Thomas [13] found a positive relationship between accounting returns and market risk. In another work, Veliyath and Ferris [14] found a significant negative relationship between accounting return and total market risk, but no significant relationship between accounting return and systematic risk (measured by the beta from the CAPM model). In conclusion, it is not clear how the accounting risk-return relationship influences the market relation, and it should be studied as part of the new research about the market risk-return relationship. It is important that the financial stream of Fama and French [1] contributes with its own conclusions.

Lastly, most of the empirical tests that have supported the existence of the paradox are cross-sectional. This creates the following problems: (1) the temporal evolution of the relationship is not well tested, so different relationships can arise, as in Fiegenbaum and Thomas [55,13]; and (2) it is possible that the variation in risk taking across firms stems from established differences among them that also produce differences in their successes [2, p. 6]. Again, a new methodology could solve these problems. The use of dynamic statistical techniques such as "panel data" could solve both problems. We can better understand the evolution of the relationship with time, and we can also examine whether the risk-return relationship depends mainly on the attitude towards risk of every manager or the established differences among firms through the whole market.

\section{Appendix A}

Empirical risk-return papers before Bowman [2], focus on prospect theory, behavioral theory, strategic position, empirical criticisms to Bowman's paradox works, and number of citations of the reviewed articles are given in Tables 16 , respectively.

Table 6

Number of citations of the reviewed articles from 1992 to February 2001

\begin{tabular}{llllllllllr}
\hline Author & 1992 & 1993 & 1994 & 1995 & 1996 & 1997 & 1998 & 1999 & 2000 & 2001 \\
\hline Bowman [2] & 5 & 3 & 4 & 2 & 9 & 5 & 6 & 4 & 4 & Total \\
Bowman [31] & 3 & 7 & 3 & 1 & 7 & 5 & 5 & 5 & 2 & 42 \\
Bettis, Hall [23] & 9 & 5 & 5 & 1 & 4 & 4 & 3 & 1 & 2 & 1 \\
Bowman [32] & & & 5 & 2 & 3 & 6 & 1 & 2 & 3 & 35 \\
Marsh, Swanson [54] & 1 & & 1 & & 3 & & & & & 22 \\
Bettis, Mahajan [24] & 4 & 4 & 4 & 1 & 3 & 5 & 1 & 2 & 2 & \\
Fiegenbaum, Thomas [55] & 1 & & 1 & & 1 & 2 & & 1 & & \\
Fiegenbaum, Thomas [13] & 2 & & 3 & & 3 & 3 & 2 & 1 & 2 & \\
Singh [41] & 6 & 4 & 11 & 6 & 14 & 14 & 9 & 2 & 8 & \\
Aaker, Jacobson [56] & 1 & & & 3 & 4 & 1 & 1 & 2 & 2 & 74
\end{tabular}


Table 6 (continued)

\begin{tabular}{|c|c|c|c|c|c|c|c|c|c|c|c|}
\hline Author & 1992 & 1993 & 1994 & 1995 & 1996 & 1997 & 1998 & 1999 & 2000 & 2001 & Total \\
\hline Fiegenbaum, Thomas [34] & 4 & 3 & 7 & 1 & 8 & 3 & 2 & 7 & 3 & 1 & 39 \\
\hline Amit, Livnat [51] & 3 & 4 & 2 & 2 & 3 & 5 & 3 & 1 & 1 & & 24 \\
\hline Cool et al. [25] & 1 & 1 & 1 & 2 & 4 & 4 & 1 & 6 & 3 & & 23 \\
\hline Chang, Thomas [20] & 2 & 2 & 1 & 1 & 1 & 2 & & & 1 & 1 & 11 \\
\hline Fiegenbaum [35] & & 1 & 1 & & 5 & 3 & & 5 & 1 & 1 & 17 \\
\hline Miller, Bromiley [26] & 4 & 2 & 4 & & 5 & 5 & 1 & 2 & 3 & & 26 \\
\hline Jegers $[36]$ & 1 & & 1 & & 4 & 1 & 1 & 1 & & & 9 \\
\hline Bromiley [42] & 2 & 3 & 2 & 1 & 11 & 7 & 7 & 9 & 4 & 1 & 47 \\
\hline Oviatt, Bauerschmidt [58] & 1 & & 1 & & 2 & 1 & & & 2 & & 7 \\
\hline Wiseman, Bromiley [59] & 1 & & 2 & 1 & 2 & & & 3 & 1 & & 10 \\
\hline Collins, Ruefli [60] & & & 1 & 1 & 2 & & & & 1 & & 5 \\
\hline Kim, Hwang, Burgers [52] & & & & & 2 & 1 & 2 & 1 & 4 & & 10 \\
\hline Baucus, Golec, Cooper [61] & & & & & 2 & 1 & & 1 & 1 & & 5 \\
\hline Sinha [37] & & & & & & & & & 1 & & 1 \\
\hline Miller, Leiblein [45] & & & & & 1 & & 4 & 3 & 2 & 1 & 11 \\
\hline Wiseman, Bromiley [46] & & & & & & & & 1 & 2 & & 3 \\
\hline Gooding et al. [38] & & & & & & & & & 1 & & 1 \\
\hline Walls, Dyer [62] & & & & & & & & 1 & & & 1 \\
\hline Lee [39] & & & & & & & & 1 & & & 1 \\
\hline Wiseman, Catanach [47] & & & & & & & & 2 & 1 & & 3 \\
\hline Greve [43] & & & & & & & 1 & 3 & 3 & & 7 \\
\hline McNamara, Bromiley [8] & & & & & & & & & & & 0 \\
\hline Palmer, Wiseman [48] & & & & & & & & & & & 0 \\
\hline Deephouse, Wiseman [27] & & & & & & & & & & & 0 \\
\hline Lehner [40] & & & & & & & & & & & 0 \\
\hline
\end{tabular}

\section{References}

[1] Fama EF, French KR. The cross-section of expected stock returns. The Journal of Finance 1992;47(2):427-65.

[2] Bowman EA. Risk/return paradox for strategic management. Sloan Management Review 1980;Spring:17-31.

[3] Fletcher J. On the conditional relationship between beta and return in international stock returns. International Review of Financial Analysis 2000;9(3):235-45.

[4] Clare AD, Priestley R, Thomas SH. Reports of beta's death are premature: Evidence from the UK. Journal of Banking \& Finance 1998;22:1207-29.

[5] Grundy K, Malkiel BG. Reports of beta's death have been greatly exaggerated. Journal of Portfolio Management 1996;22:36-44.

[6] Hodoshima J, Garza-Gómez X, Kunimura M. Cross-sectional regresión análisis of return and beta in Japan. Journal of Economics and Business 2000;52:515-33.

[7] Wang X. Size effect, book-to-market effect, and survival. Journal of Multinational Financial Management 2000;10:25773.

[8] McNamara G, Bromiley P. Risk and return in organizational decision making. Academy of Management Journal 1999;42(3):330-9.

[9] Ruefli T, Collins JM, LaCugna JR. Risk measurement in strategic management research: Auld lang syne? Strategic Management Journal 1999;20:167-94.

[10] Campbell JY. Asset pricing at the millennium. The Journal of Finance 2000;55(4):1515-67.

[11] Fama EF, French R. The CAPM is wanted, dead or alive. The Journal of Finance 1996;51(5):1947-58.
[12] Kim MK, Ismail BE. An accounting analysis of the risk-return relationship in bull and bear markets. Review of Financial Economics 1998;7(2):173-82.

[13] Fiegenbaum A, Thomas H. Dynamic and risk measurement. Perspectives on Bowman's risk-return paradox for strategic management: An empirical study. Strategic Management Journal 1986;7:395-407.

[14] Veliyath R, Ferris SP. Agency influences on risk reduction and operating performance: an empirical investigation among strategic groups. Journal of Business Research 1997;39: 219-30.

[15] Chatterjee S, Lubatkin MH, Schulze WS. Toward a strategic theory of risk premium: moving beyond CAPM. Academy of Management Review 1999;24(3):556-67.

[16] Conrad G, Plotkin I. Risk/return: U.S. industry pattern. Harvard Business Review 1968;46(2):90-9.

[17] Fisher IN, Hall GR. Risk and corporate rates of return. Quarterly Journal of Economics 1969;83:79-92.

[18] Hurdle G. Leverage, risk, market structure and profitability. The Review of Economics and Statistics 1974;66(4):78-85.

[19] Armour H, Teece D. Organizational structure and economic performance: a test of multidivisional hypothesis. The Bell Journal of Economics 1978;9:106-22.

[20] Chang Y, Thomas H. The impact of diversification strategy on risk-return performance. Strategic Management Journal 1989;10:271-84.

[21] Kahneman D, Tversky A. Prospect theory: an analysis of decision under risk. Econometrica 1979;47(2):263-91.

[22] Cyert RM, March JG. A behavioral theory of the firm. Englewood Cliffs, NJ: Prentice-Hall, 1963. 
[23] Bettis R, Hall W. Diversification strategy, accounting determined risk, and accounting determined return. Academy of Management Journal 1982;25(2):254-64.

[24] Bettis R, Mahajan V. Risk/return performance of diversified firms. Management Science 1985;31(7):785-99.

[25] Cook K, Dierickx I, Jemison D. Business strategy, market structure and risk-return relationships: a structural approach. Strategic Management Journal 1989;10:507-22.

[26] Miller K, Bromiley P. Strategic risk and corporate performance: an analysis of alternative risk measures. Academy of Management Journal 1990;33(4):756-79.

[27] Deephouse DL, Wiseman RM. Comparing alternative explanations for accounting risk-return relations. Journal of Economic Behavior and Organization 2000;42:463-82.

[28] Latour B. Science in action. Cambridge, MA: Harvard University Press, 1987.

[29] Tobin J. Liquidity preference as behavior towards risk. Review of Economic Studies 1958;26:65-86.

[30] March J. Variable risk preferences and adaptive aspirations. Journal of Economic Behavior and Organization 1988;9:5-24.

[31] Bowman E. Risk seeking by troubled firms. Sloan Management Review 1982;31(Summer):33-42.

[32] Bowman E. Content analysis of annual reports for corporate strategy and risk. Interfaces 1984;61-71.

[33] Lipe MG. Individual investors' risk judgments and investment decisions: the impact of accounting and market data. Accounting, Organizations \& Society 1998;23(7):625-40.

[34] Fiegenbaum A, Tomas H. Attitudes toward risk and the riskreturn paradox: prospect theory explanations. Academy of Management Journal 1988;31(1):85-106.

[35] Fiegenbaum A. Prospect theory and the risk-return association: an empirical examination of 85 industries. Journal of Economic Behavior and Organization 1990;14:187-203.

[36] Jegers M. Prospect theory and the risk-return relation: Some Belgian evidence. Academy of Management Journal 1991;34(1):215-25.

[37] Sinha T. Prospect theory and the risk return association: another look. Journal of Economic Behavior and Organization 1994;24:225-31.

[38] Gooding RZ, Goel S, Wiseman RM. Fixed versus variable reference points in the risk-return relationship. Journal of Economic Behavior and Organization 1996;29:331-50.

[39] Lee DY. The impact of poor performance on risk-taking attitudes: a longitudinal study with a PLS causal modeling approach. Decision Sciences 1997;28(1):59-80.

[40] Lehner JM. Shifts of reference points for framing of strategic decisions and changing risk-return associations. Management Science 2000;46(1):63-76.

[41] Singh JV. Performance, slack, and risk taking in organizational decision making. Academy of Management Journal 1986;29(3):562-85.

[42] Bromiley P. Testing a causal model of corporate risk taking and performance. Academy of Management Journal 1991;24(1):37-59.

[43] Greve HR. Performance, aspirations and risky organizational change. Administrative Science Quarterly 1998;43:58-86.

[44] Grinyer P, McKiernan P. Generating major change in stagnating companies. Strategic Management Journal 1990;11:131-46.

[45] Miller K, Leiblein M. Corporate risk-return relations: returns variability versus downside risk. Academy of Management Journal 1996;39(1):91-122.
[46] Wiseman RM, Bromiley P. Toward a model of risk in declining organizations: an empirical examination of risk, performance and decline. Organization Science 1996;7(5):524-43.

[47] Wiseman RM, Catanach AH. A longitudinal disaggregation of operational risk under changing regulations: evidence from the savings and loan industry. Academy of Management Journal 1997;40(4):799-830.

[48] Palmer TB, Wiseman RM. Decoupling risk taking from income stream uncertainty: a holistic model of risk. Strategic Management Journal 1999;20:1037-62.

[49] Fiegenbaum A, Hart S, Schendel D. Strategic reference point theory. Strategic Management Journal 1996;17:219-35.

[50] Staw BM, Sandelands LE, Dutton JE. Threat-rigidity effects in organizational behavior: a multilevel analysis. Administrative Science Quarterly 1981;26:501-24.

[51] Amit R, Livnat J. Diversification and the risk-return trade-off. Academy of Management Journal 1988;31(1):154-66.

[52] Kim WC, Hwang P, Burgers WP. Multinationals' diversification and the risk-return trade-off. Strategic Management Journal 1993;14:275-86.

[53] Woo C. Path analysis of the relationship between market share, business-level conduct and risk. Strategic Management Journal 1987;8:149-68.

[54] Marsh T, Swanson D. Risk-return tradeoffs for strategic management. Sloan Management Review 1984; Spring:35-51.

[55] Fiegenbaum A, Thomas H. An examination of the structural stability of Bowman's risk-return paradox. Academy of Management Proceedings, 1985. p. 7-10.

[56] Aaker DA, Jacobson R. The role of risk in explaining differences in profitability. Academy of Management Journal 1987;30(2):277-96.

[57] Fiegenbaum A, Thomas H. Stakeholder risk and Bowman's risk-return paradox. In: Bettis R, Thomas H, editors. Risk, strategy and management. Greenwich, CT: JAI Press, 1990. p. 111-33.

[58] Oviatt B, Bauerschmidt A. Business risk and return. A test of simultaneous relationships. Management Science 1991;37(11):1405-23.

[59] Wiseman R, Bromiley P. Risk-return associations: paradox or artifact? An empirical tested explanation. Strategic Management Journal 1991;12:231-41.

[60] Collins J, Ruefli T. Strategic risk: an ordinal approach. Management Science 1992;38(12):1707-31.

[61] Baucus D, Golec J, Cooper J. Estimating risk-return relationships: an analysis of measures. Strategic Management Journal 1993;14:387-96.

[62] Walls MR, Dyer JS. Risk propensity and firm performance: a study of the petroleum exploration industry. Management Science 1996;42(7):1004-21.

[63] Baird IS, Thomas H. Toward a contingency model of strategic firm risk taking. Academy of Management Review 1985;10:230-43.

[64] March J, Shapira Z. Managerial perspectives on risk and risk taking. Management Science 1987;33(11):1404-18.

[65] Sitkin SB, Pablo AL. Reconceptualizing the determinants of risk behavior. Academy of Management Review 1992;17(1):9-38.

[66] Baird IS, Thomas H. What is risk anyway? In: Bettis $\mathrm{R}$, Thomas H, editors. Risk, strategy and management. Greenwich, CT: JAI Press, 1990. p. 111-33. 
[67] Libby R, Fishburn PC. Behavioral models of risk taking in business decisions: a survey and evaluation. Journal of Accounting Research 1977;15:272-92.

[68] Ruefli T. Mean-variance approaches to risk-return relationships in strategy: paradox lost. Management Science 1990;36(3):368-80.

[69] Ruefli T. Reply to Bromiley's comment and further results: paradox lost becomes dilemma found. Management Science 1991;37(9):1210-5.

[70] Ruefli T, Wiggins R. When mean square error becomes variance: a comment on 'business risk and return: a test of simultaneous relationships'. Management Science 1994;40(6):750-9.

[71] Bromiley P. Paradox or at least variance found: a comment on 'mean-variance approaches to risk-return relationships in strategy: paradox lost'. Management Science 1991;37(9):1206-15.

[72] Burgstahler D, Dichev I. Earnings management to avoid earnings decreases and losses. Journal of Accounting and Economics 1997;24:99-126.

[73] Degeorge R, Patel J, Zeckhauser R. Earnings management to exceed thresholds. Journal of Business 1999;72:1-33. 